\title{
Når omentet snur seg
}
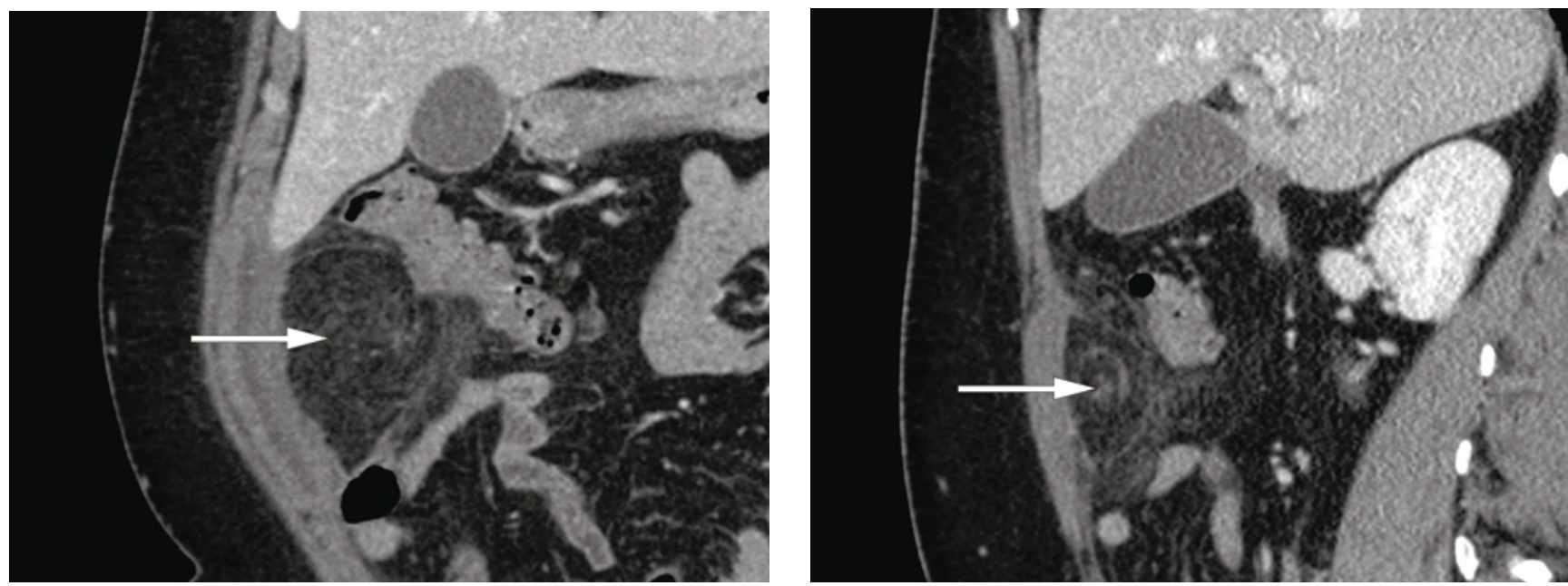

En kvinne i 40-årene ble innlagt med magesmerter, mest uttalt under høyre kostalbue. Smertene var konstante og hadde oppstått tre dager tidligere. Hun var ikke tidligere operert i buken. Ved klinisk undersøkelse var abdomen bløt med palpasjonsømhet i øvre høyre kvadrant. Bortsett fra forhøyet CRP på $80 \mathrm{mg} / \mathrm{l}(<5)$ var alle blodprøver normale. Ultralydundersøkelse av lever, galleblære og pancreas ved innkomst viste upåfallende forhold. På grunn av vedværende sterke smerter ble pasienten undersøkt med CT abdomen samme dag. CT-undersøkelsen viste et avkapslet område av mesenterialt fettvev ventralt i øvre høyre kvadrant. I koronalplan (bilde til venstre) indikerer pilen det avkapslede området. I sagittalplan (bilde til høyre) så man tydelig en spiralformet forandring, som kunne representere roterte kar og mesenteriale strukturer (pil). Pasienten ble laparoskopert og det ble funnet en partiell torsjon av omentum majus. Det torkverte segment lå adherent mot bukveggen og inneholdt begynnende nekrotiske forandringer og ble fjernet.

Primær (idiopatisk) torsjon av omentum majus er en sjelden differensialdiagnose ved akutte magesmerter (1), og hyppigere hos menn enn hos kvinner. Det kliniske bildet kan likne appendisitt eller kolecystitt. Bildediagnostikk vil som oftest gi diagnosen, men noen ganger oppdages ikke tilstanden før ved laparoskopi (2).

Pasienten har gitt samtykke til at artikkelen blir publisert.

\section{Johannes Godt}

uxgodj@ous-hf.no

Avdeling for radiologi og nukleærmedisin

\section{Christer Kubon}

Avdeling for gastro-og barnekirurgi

\section{Tom Hirschberg}

Avdeling for radiologi og nukleærmedisin

Oslo universitetssykehus, Ullevål

Johannes Godt (f. 1980) er lege i spesialisering i radiologi.

Forfatteren har fylt ut ICMJE-skjemaet og oppgir ingen interessekonflikter.
Christer Kubon (f. 1983) er lege i spesialisering i generell kirurgi.

Forfatteren har fylt ut ICMJE-skjemaet og oppgir ingen interessekonflikter.

Tom Hirschberg (f.1961) er spesialist i radiologi og overlege ved seksjon for abdominal- og onkologisk radiologi.

Forfatteren har fylt ut ICMJE-skjemaet og oppgir ingen interessekonflikter.

\section{Litteratur}

1. Andreuccetti J, Ceribelli C, Manto 0 et al. Primary omental torsion (POT): a review of literature and case report. World J Emerg Surg 2011; 6: 6 .

2. Tsironis A, Zikos N, Bali C et al. Acute abdomen due to primary omental torsion: case report. J Emerg Med 2013; 44: e45-8.

Mottatt 13.4. 2012, første revisjon innsendt 6.9. 2012, godkjent 3.12. 2012. Medisinsk redaktør Merete Kile Holtermann. 